\title{
Government education expenditures and economic growth: a meta-analysis
}

\author{
${ }^{1}$ RMIT University, School of Economics, Finance and Marketing, Melbourne, Victoria, Australia, E-mail: \\ sefa.awaworyichurchill@rmit.edu.au.http://orcid.org/0000-0002-1930-9177. \\ ${ }^{2}$ University of Greenwich, London, London, United Kingdom of Great Britain and Northern Ireland \\ ${ }^{3}$ Monash University, Caulfield Campus, Department of Economics, Caulfield East, Victoria, Australia
}

\begin{abstract}
:
Using a sample of 237 estimates drawn from 29 primary studies, we conduct a hierarchical meta-regression analysis that examines the association between economic growth and government expenditure on education. We find that the effect of government education expenditure on growth is positive for developed countries. However, when the evidence pertains to less developed countries (LDCs), we find a statistically insignificant association. We also examine the heterogeneity in empirical results and found that factors such as econometric specifications, publication characteristics as well as data characteristics explain the heterogeneity in the literature. We find no evidence of publication selectivity.
\end{abstract}

Keywords: economic growth, government education expenditure, human capital

JEL classification: $\mathrm{H} 52, \mathrm{O} 4$

DOI: $10.1515 /$ bejm-2016-0109

Received: November 26, 2016; Accepted: January 9, 2017

\section{Introduction}

Economists have long recognized that human capital is important for economic growth (see, e.g. Schultz 1961; Becker 1964; Rosen 1976; Uzawa 1965). Schultz asserts that investments in human capital such as expenditures on education account for most of the rise in the real earnings per worker. According to Becker (1964), investments in human capital raise an individual's productivity and earnings. The basic idea is that a highly educated workforce is expected to be relatively more productive. Subsequent work has also emphasized the importance of human capital in explaining growth or growth differences among countries (see, e.g. Barro and Sala-i-Martin 1995; Lucas 1988; Mulligan and Sala-I-Martin 1993).

There are empirical studies that confirm human capital is important for long-run growth (see, e.g. Romer 1986; Barro 1991; Levine and Renelt 1992; Mankiw, Romer, and Weil 1992; Barro and Lee 1993; Bassanini and Scarpetta 2001; Krueger and Lindahl 2001; Baldacci et al. 2004). However, some other studies have surprisingly found weak association between human capital and growth, and even negative effects (see Knight, Loayza, and Villanueva 1993; Benhabib and Spiegel 1994; Islam 1995; Caselli, Esquivel, and Lefort 1996; Pritchett 1996; Bils and Klenow 2000). There are several explanations for the lack of a robust association between human capital and growth. For instance, according to Levine and Renelt (1992), model specification and the inclusion or exclusion of certain control variables could explain differences in reported estimates.

In this paper, we re-assess the growth effect of government education expenditure (GE). As it stands, the empirical evidence about the growth impacts of government education expenditure is mixed and inconclusive. ${ }^{1}$ Thus, we combine results from various studies that empirically investigate the effect of government education expenditure on economic growth to identify sources of heterogeneity amongst these results, and to derive a more precise effect size estimate than that derived in a single empirical study.

Since human capital investments are essential for the accumulation of human capital, and human capital has been stressed as the key engine of growth in endogenous growth theory, we formulate hypotheses that reflect a positive GE-growth association. Thus, based on 29 primary studies with 237 meta-estimates, we formulate three hypotheses (H1-H3) to examine the GE-growth relationship: (H1) government education expenditure as a share of GDP promotes growth, $(\mathrm{H} 2)$ government education expenditure as a share of GDP promotes growth in developed countries, and (H3) government education expenditure as a share of GDP promotes growth in lessdeveloped counties (LDCs). Overall, we find that the effect of government education expenditure on growth is 
positive, and this is also the case when the evidence pertains to developed countries only. However, the effects in LDCs is statistically insignificant.

This study makes a number of important contributions. First, we investigate if "genuine" effect beyond publication bias exists between GE and economic growth. Without any control for publication bias, results from empirical literature could be misleading ( Stanley 2008) and thus, could impede the policy formulation process. We deal with issues of publication selection bias, and accordingly provide a statistically valid conclusion on the relationship between GE and growth.

Second, we investigate various sources of heterogeneity in the empirical literature that examines the GEgrowth relationship. Without addressing issues of heterogeneity, a general conclusion cannot be drawn on the GE-growth relationship. This is mainly due to the disparity in the empirical literature, especially with regards to the data used, estimation methods, and the underlying theoretical models, among others. Thus, with the use of meta-regression analysis, we control for study-to-study variations which allow for the determination of a net effect of GE on growth.

Third, we capture country differences and provide a general conclusion per development level (i.e. developed countries and LDCs). With our results, we lay a foundation for, and guide future studies in examining areas of particular importance in the human capital expenditure-growth literature. To the best of our knowledge, this is the first study that presents a detailed empirical synthesis on the GE-growth relationship using meta-analysis. Benos and Zotou (2014), using meta-analysis, investigate a similar research question. However, rather than the growth effects of GE, they examine the effect of education in general measured by literacy, enrolment, education expenditure and schooling years, on economic growth. They provide evidence of publication bias towards the positive effects of education on growth. Effects of education on growth also vary significantly depending on the measure of education.

This current study is relevant in practice, given the ongoing debate on how various components of government expenditure affect growth. Thus, from the policy perspective, our results suggest that education is a relevant sector in promoting growth. Therefore, to promote growth, education may be a key sector to which public expenditure should be directed in the context of tight government budget constraints or budget deficits.

\section{Brief overview of existing perspectives}

Education has been considered as one of the most significant investments in human capital and has been discussed extensively in the literature of economic growth. It has been argued that education can affect growth through many different mechanisms. For instance, education can affect growth by increasing the efficiency of the workforce, by reducing inequality, by promoting health, by reducing fertility levels, by creating better conditions for good governance, and by increasing the knowledge and the innovative capacity of an economy Lipset 1960; Benhabib and Spiegel 1994; Aghion, Caroli, and García-Peñalosa 1999; Glaeser et al. 2004; CastellóCliment 2008; Castelló-Climent and Doménech 2008; Hanushek and Woessmann 2008).

There are many theoretical papers that investigate the interaction between government education expenditure and growth. Among those papers are Glomm and Ravikumar (1992, 1997, 1998), Eckstein and Zilcha (1994), Zhang (1996), Kaganovich and Zilcha (1999), Cassou and Lansing (2001), Benabou (2002), Blankeanu (2005), and Wigger (2004). Glomm and Ravikumar (1992), for instance, examine the implication of schooling on growth and income inequality and find that public education can yield greater per capita income when the initial income inequality is sufficiently high in an overlapping-generations model. Zhang (1996) finds that education subsidization stimulates growth and reduces welfare losses caused by human capital externalities.

The empirical evidence with regards to government education expenditure and economic growth however has been mixed. Zhang and Casagrande (1998), Barro and Sala-i-Martin (1995), and Baldacci et al. (2008) find a positive association between government education expenditure and economic growth. Easterly and Rebelo (1993) find the positive relationship only for some specifications, while Devarajan, Swaroop, and Zou (1996), Landau (1986), Levine and Renelt (1992), and Keller (2006) find insignificant connection between the two.

\section{Data and methodology}

\subsection{Data}

We draw on guiding principles proposed by the meta-analysis of economics research-network (MAER-Net), which reflects transparency and the "best practices" in meta-analysis ( Stanley et al. 2013). To identify relevant studies that examine the relationship between government expenditure on education (GE) and growth, we 
search for journal articles and working papers in five major electronic databases - EconLit, Business Source Compete, Google Scholar, JSTOR and ProQuest. We use various keywords for GE and growth. ${ }^{2}$ In addition, we also search through the references of related studies on GE and growth to ensure that our meta-analysis includes all relevant studies.

We adopt the following criteria to determine studies that we include in our meta-analysis. (1) We include only empirical studies that examine the direct effect of GE on growth. Thus, studies that examine measures of education other than government education expenditure, such as years of education and literacy rate, among others, are excluded. Similarly, studies that examine the impact of education expenditures using measures other than government education expenditure are also excluded. ${ }^{3}$ (2) Government education expenditure must be an independent variable and must be measured as a proportion of GDP. Thus, studies that use government education expenditure as a share of total government expenditure are excluded.

From an empirical perspective, we consider empirical studies that adopt some variant of the following growth model, and examine the GE-growth relationship.

$$
g_{i t}=\alpha_{0}+\alpha_{1} G_{i t}+\sum_{j} \alpha_{j} z_{j, i t}+\varepsilon_{i t}
$$

where $g$ is the measure of economic growth and $G$ is the share of government education expenditure to GDP. $z_{j}$ is a set of control variables often used in the economic growth literature, and are theoretically supported such as initial level of per-capita GDP, and investment in human or physical capital, among others. The $i$ and $t$ subscripts represent institutional/country and time dimensions, respectively. Specifications of this kind have been widely used in the empirical growth literature.

Lastly, to allow for comparability of studies, we calculate partial correlation coefficients. For studies that satisfy criteria (1) and (2) above but do not report relevant statistics to allow for the calculation of partial correlation coefficients are excluded as well.

Following the above criteria, we find 29 relevant studies with 237 estimates which are included in this metaanalysis. Table 1 presents an overview of these 29 studies in terms of their simple and fixed effect weighted means, and the corresponding number of estimated extracted from each primary study.

Table 1: Overview of evidence base per study (simple \& fixed effect weighted means).

\begin{tabular}{|c|c|c|c|c|c|}
\hline Paper & No. of estimates & Simple mean & $\begin{array}{r}\text { Weighted mean } \\
\text { (FE) }\end{array}$ & Significance & $\begin{array}{r}\text { Confidence } \\
\text { interval }\end{array}$ \\
\hline \multicolumn{6}{|l|}{ Education } \\
\hline $\begin{array}{l}\text { Afonso and } \\
\text { Jalles (2013) }\end{array}$ & 21 & 0.1277 & 0.1335 & Yes & $(0.1072,0.1598)$ \\
\hline $\begin{array}{l}\text { Barro and } \\
\text { Sala-i-Martin } \\
\text { (1995) }\end{array}$ & 24 & 0.1965 & 0.1988 & Yes & $(0.1557,0.2419)$ \\
\hline $\begin{array}{l}\text { Barro and } \\
\text { Sala-i-Martin } \\
(2004)\end{array}$ & 1 & -0.1268 & -0.1268 & & \\
\hline Barro (1989) & 1 & 0.4035 & 0.4035 & & \\
\hline $\begin{array}{l}\text { Blankenau, } \\
\text { Simpson, and } \\
\text { Tomljanovich } \\
\text { (2007) }\end{array}$ & 3 & -0.0495 & -0.0496 & No & $(-0.1600,0.0609)$ \\
\hline Bojanic (2013) & 3 & 0.1066 & 0.1091 & No & $(-0.2534,0.4716)$ \\
\hline $\begin{array}{l}\text { Bose, Haque, } \\
\text { and Osborn } \\
(2007)\end{array}$ & 8 & 0.4340 & 0.4384 & Yes & $(0.3817,0.4950)$ \\
\hline $\begin{array}{l}\text { Yan and Gong } \\
\text { (2009) }\end{array}$ & 4 & -0.0175 & -0.0543 & No & $(-0.2292,0.1207)$ \\
\hline $\begin{array}{l}\text { Colombier } \\
\text { (2009) }\end{array}$ & 4 & -0.0161 & -0.0168 & No & $(-0.0537,0.0200)$ \\
\hline Cooray (2009) & 5 & 0.1331 & 0.1337 & Yes & $(0.0686,0.1989)$ \\
\hline Dalic (2013) & 12 & 0.0211 & 0.0237 & No & $(-0.0164,0.0641)$ \\
\hline Diamond & 1 & -0.0540 & -0.0540 & & \\
\hline
\end{tabular}


Dunne and

Mohammed

(1995)

Easterly and

Rebelo (1993)

Hansson and

Henrekson

(1994)

Keller (2006)

Kelly (1997)

Landau (1983)

Landau (1986)

Landau (1997)

Miller and

Russek (1997)

Miyakoshi et

al. (2010)

Mo (2007)

Neycheva

(2010)

Perotti (1996)

Singh and

Weber (1997)

Stroup and

Heckelman

(2001)

Sylwester

(2000)

Zhang and

Casagrande

(1998)

\begin{tabular}{|c|c|c|c|c|}
\hline 3 & -0.0301 & -0.0301 & No & $(-0.2762,0.2160)$ \\
\hline 3 & 0.0414 & 0.0414 & Yes & $(0.0186,0.0642)$ \\
\hline 4 & 0.1407 & 0.1411 & Yes & $(0.0749,0.2073)$ \\
\hline 18 & -0.0723 & -0.0070 & No & $(-0.3002,0.2862)$ \\
\hline 12 & -0.1820 & -0.1852 & Yes & $\begin{array}{r}(-0.2414 \\
-0.1291)\end{array}$ \\
\hline 14 & 0.5665 & 0.5740 & Yes & $(0.5286,0.6195)$ \\
\hline 12 & 0.0267 & 0.0333 & Yes & $(0.0230,0.0435)$ \\
\hline 9 & -0.0396 & -0.0458 & No & $(-0.0939,0.0023)$ \\
\hline 6 & -0.0400 & -0.0871 & No & $(-0.2548,0.0806)$ \\
\hline 9 & -0.0545 & -0.0372 & No & $(-0.0840,0.0095)$ \\
\hline 10 & -0.1268 & -0.1277 & Yes & $\begin{array}{l}(-0.1754 \\
-0.0800)\end{array}$ \\
\hline 27 & 0.3493 & 0.3248 & Yes & $(0.3008,0.3489)$ \\
\hline 2 & 0.0796 & 0.0796 & No & $(-0.1293,0.2885)$ \\
\hline 3 & 0.7837 & 0.7839 & Yes & $(0.7639,0.8038)$ \\
\hline 5 & 0.2027 & 0.2266 & Yes & $(0.0183,0.4348)$ \\
\hline 11 & 0.1264 & 0.1456 & No & $(-0.0417,0.3329)$ \\
\hline 2 & 0.2586 & 0.2586 & Yes & $(0.1793,0.3380)$ \\
\hline 237 & 0.1263 & 0.0828 & & \\
\hline
\end{tabular}

\subsection{Partial correlation coefficient}

To ensure a meaningful comparison of studies, we first calculate partial correlation coefficients (PCCs) that measure the impact of government education expenditure on growth while holding other factors constant. Given that different factors are held constant in different primary studies, and in some cases, all relevant covariates are not controlled for in regressions, PCCs may be biased. This also leads to heterogeneity in reported estimates. However, this does not render PCCs irrelevant as we examine in our meta-regressions whether control variables used by primary studies affect reported estimates. Based on Greene (2011), we calculate PCCs directly from primary study regression outputs using equation (1). We also calculate corresponding standard errors using equation (2).

$$
r_{i}=\frac{t_{i}}{\sqrt{t_{i}^{2}+d f_{i}}}
$$

and

$$
S E_{r i}=\sqrt{\frac{1-r_{i}^{2}}{d f_{i}}}
$$

where $r_{i}$ and $S E_{r i}$ are the PCC and corresponding standard errors to be calculated from individual studies. $t_{i}$ and $d f_{i}$ are the $t$-statistic and degrees of freedom that correspond with each estimates reported in the primary studies. 


\subsection{Meta-analysis: tools and methods}

In order to understand and have a clear overview of the evidence base on the GE-growth relationship, we calculate fixed effect weighted averages for the estimates extracted from the primary studies. We use fixed effect weighted averages because they are more reliable than simple means, and are also less affected by publication bias compared to random effect weighted averages ( Stanley 2008; Henmi and Copas 2010; Stanley and Doucouliagos 2014). In addition, with the inverse of the variance used as weight, fixed effect weighted averages assign higher weights to more precise estimates, and lower weights to less precise ones. The fixed effect average $\left(X_{E}\right)$ is calculated using equation (3) below:

$$
\bar{X}_{\mathrm{FE}}=\frac{\sum r_{i j}\left(\frac{1}{S E_{r i j}^{2}}\right)}{\sum \frac{1}{S E_{r i j}^{2}}}
$$

where $r_{i j}$ is the estimated $i$ th PCC in study $j$, and $S E_{r i j}^{2}$ is the corresponding variance.

Table 1 presents the fixed effect weighted averages. Twenty nine studies with a total of 237 estimates report on the relationship between government education expenditure and growth. Based on the fixed effects weighted averages, we find that 85 estimates (35.86\% of total estimates) are statistically insignificant. 128 estimates (54.01\% of total estimates) are positive and significant, whereas the remaining 24 estimates $(10.13 \%$ of total estimates) are negative. The overall weighted average for all 237 estimates is found to be 0.0828 . This suggests that government education expenditure has a positive effect on growth.

Based on the guidelines presented by Doucouliagos (2011) ${ }^{4}$ the overall weighted averages for explaining the effects of government education expenditure on growth, i.e. 0.0828 represent a small effect with very little economic significance. However, if the reported weighted averages are fraught with issues of publication bias, they cannot represent genuine measures of the effects on growth (De Dominicis, Florax, and Groot 2008; Doucouliagos and Stanley 2009). Thus, in the next section, to investigate the robustness of our fixed effect weighted averages, we examine if the reported estimates are tainted with publication bias.

\subsubsection{Detecting and correcting publication bias}

Publication selection bias occurs when authors, reviewers and editors select statistical significant results consistent with theory to justify model selection ( Stanley 2008). To examine if the reported estimates are subject to publication bias, we first present a funnel plot, which shows the relation between PCCs and their precision $\left(1 / S E_{r i}\right)$. In the absence of publication bias, funnel plots should resemble a symmetric funnel and thus, an asymmetric funnel plot suggests publication bias ( Stanley and Doucouliagos 2010). Figure 1 is a funnel plot of the estimated effected sizes of government education expenditure on growth against their precision. 


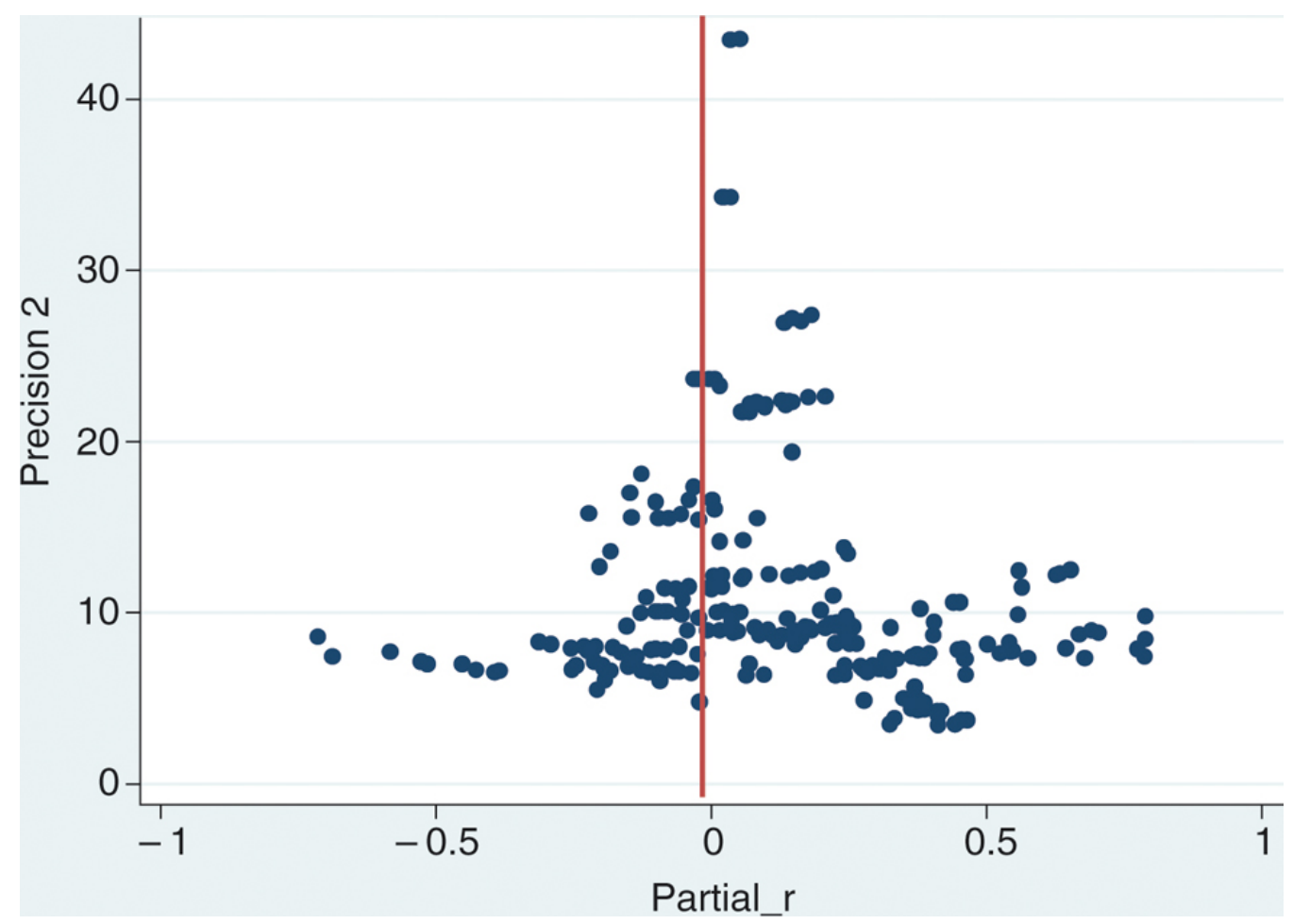

Figure 1: Funnel plot of the estimated effected sizes of government education expenditure on growth against their precision.

A visual inspection of the funnel plots reveals not much signs of asymmetries with regards to our reference lines. This suggests that publication bias may not be an issue in the GE-growth literature. However, although funnel plots may be useful, they are only indicative and do not provide definite evidence on the presence or absence of bias. In addition, they are not very useful in determining the magnitude and significance of bias. Therefore, to thoroughly examine issues of publication bias, we adopt a more formal analysis - the precision effect test (PET) and the funnel asymmetry test (FAT). PET/FAT analyses ( Egger et al. 1997; Stanley 2008) are able to help establish if reported estimates are tainted with publication bias and whether they represent genuine effect beyond bias. Stanley (2008) demonstrates that the weighted least squares (WLS) bivariate model in equation (4) can be used to test for both publication bias (FAT) and for genuine effect beyond bias (PET):

$$
t_{i}=\alpha_{0}+\beta_{0}\left(\frac{1}{S E_{r i}}\right)+\varepsilon_{i}
$$

where $t_{i}$ is the $t$-value and $1 / S E_{r i}$ is the precision. $H_{0}: \alpha_{0}=0$ and $H_{0}: \beta_{0}=0$ are tests for the absence/presence of publication bias (FAT) and genuine effect (PET), respectively. Hence, at conventional levels, there is evidence of bias if $\alpha_{0}$ is statistically significant, and evidence of genuine effect if $\beta_{0}$ is statistically significant.

Given that several observations are clustered within the primary studies, the data used in this meta-analysis are characterized by an inherent hierarchical structure. Thus, in our case, the estimation of equation (4) with OLS may be erroneous and prone to various criticisms. This is because the assumption that the reported effect sizes are independently distributed may be flawed. Some researchers resort to the use of single effect size estimates for each primary study. However, this approach is often criticized on the grounds of subjectivity, given that the criteria used in the selection of that single estimate is considered subjective. In addition, this approach does not represent the overall evidence base as several effect size estimates are excluded.

This data dependence can also be addressed by: (i) conducting clustered data analysis (CDA); or (ii) using hierarchical linear models ( Doucouliagos and Laroche 2009). The first approach only corrects the standard errors for within-study dependence. Hierarchical linear models (HLMs), however, allow for robust standard errors clustered on studies and take account of both within-study and between-study dependence explicitly. An added feature is that HLMs allow for a range of likelihood ratio (LR) tests to choose how dependence should be modeled.

We model data dependence by allowing for random variation between study-specific estimates, which may be due to study-specific intercepts and/or study-specific slopes ( Demidenko 2004; McCulloch, Searle, and Neuhaus 2008). Put differently, expenditure estimates reported by primary studies are nested within each study; and the estimates are modelled to differ between studies either because they share a common intercept (a fixed component) and/or a common slope within each primary study. 
Therefore, we estimate model (5) as an HLM. The HLM approach has been used in various meta-analyses to deal with issues of data dependence (see e.g. Bateman and Jones 2003; De Dominicis, Florax, and Groot 2008; Alptekin and Levine 2012). Using results from likelihood ratio tests, which compare HLM to the standard OLS, we confirm that the HLM in the case of our dataset is preferred to OLS. Our preference for the random effect model over the fixed effect model is also determined, first, by the traditional Hausman test. Additionally, evidence provided by Stanley and Doucouliagos (2016) suggest that the random effect model is superior if publication selection bias can be ruled out, which is the case in our analysis. Further, the HLM estimations are fitted via maximum likelihood (ML). The use of ML is preferred given that it allows us to cluster standard errors whereas other specifications such as the restricted maximum likelihood (REML) does not. Additionally, simulation evidence suggests that method of moment and empirical Bayes estimations tend to overestimate within-study standard errors ( Sutton and Higgins 2008).

$$
t_{i j}=\alpha_{0}+\beta_{0}\left(\frac{1}{S E_{r i j}}\right)+v_{j}+\varepsilon_{i j}
$$

where $t_{i j}$ is $i$ th $t$-value in study $j$, and $1 / S E_{r i}$ is the, precision. $\varepsilon_{i j}$ is the normally distributed estimate-level error term, whereas $v_{j}$ is the study-level error term which captures between-study variations.

Egger et al. (1997) assume a linear relationship between primary-study estimates and their standard errors. However, Stanley and Doucouliagos (2014) provide simulation evidence indicating that a quadratic specification is superior if "genuine effect" exists beyond selection bias - i.e. if the PET in (5) rejects the null hypothesis of zero effect. Then, the correct specification is referred to as precision-effect test corrected for standard errors (PEESE) and can be stated as follows:

$$
t_{i j}=\beta_{0}\left(\frac{1}{S E_{r i j}}\right)+\alpha_{0}\left(S E_{r i j}\right)+v_{j}+\varepsilon_{i j}
$$

Table 2 presents results from our PET-FAT analysis. We report results for both CDA and HLM. As noted earlier, our preferred model is the HLM, and thus CDA results are reported for comparison only. Columns 1-3 report CDA results, while columns 4-6 report HLM results for the full sample, developed country sample, and less developed countries (LDCs) sample, respectively. Overall, both CDA and HLM results suggest a positive association between government education expenditure and growth when the evidence pertains to the full sample and developed countries only. However, when the evidence pertains to less developed countries (LDCs), we find that the coefficient of the precision is statistically insignificant, suggesting no statistically significant effect of government education expenditures on growth in LDCs. ${ }^{5}$

\begin{tabular}{|c|c|c|c|c|c|c|}
\hline \multirow[t]{2}{*}{ Variables } & \multicolumn{3}{|c|}{ Clustered data analysis } & \multicolumn{3}{|c|}{ Hierarchical model } \\
\hline & $\begin{array}{r}\text { Full sample } \\
\text { (1) }\end{array}$ & $\begin{array}{r}\text { Developed } \\
\text { (2) }\end{array}$ & LDCs (3) & $\begin{array}{r}\text { Full sample } \\
\text { (4) }\end{array}$ & $\begin{array}{r}\text { Developed } \\
\text { (5) }\end{array}$ & LDCs (6) \\
\hline Precision $\left(\beta_{0}\right)$ & $\begin{array}{r}.0758^{* * * *} \\
(0.0267)\end{array}$ & $\begin{array}{r}.2204^{* * * *} \\
(0.0406)\end{array}$ & $\begin{array}{r}0.0321 \\
(0.0261)\end{array}$ & $\begin{array}{r}0.0768^{* * * *} \\
(0.0267)\end{array}$ & $\begin{array}{r}0.2320^{* * * *} \\
(0.0390)\end{array}$ & $\begin{array}{r}0.0316 \\
(0.0259)\end{array}$ \\
\hline $\operatorname{Bias}\left(\alpha_{0}\right)$ & $\begin{array}{r}0.1122 \\
(0.4928)\end{array}$ & $\begin{array}{l}-0.9834 \\
(0.9343)\end{array}$ & $\begin{array}{r}1.1462 \\
(0.7561)\end{array}$ & $\begin{array}{r}0.1000 \\
(0.4971)\end{array}$ & $\begin{array}{l}-1.1318 \\
(1.0600)\end{array}$ & $\begin{array}{l}1.1558^{*} \\
(0.7020)\end{array}$ \\
\hline Observations & 237 & 71 & 40 & 237 & 71 & 40 \\
\hline
\end{tabular}

Table 2: PET/FAT results.

Standard errors in parentheses

$* * * 0<0.01, * * p<0.05, * p<0.1$.

Specifically, for the full sample, HLM results suggest a positive association between government education expenditure and growth, with no evidence of publication bias. The effect size is 0.0768 , which represents a small empirical effect. Considering the sample of developed countries only, we find a stronger positive effect size of 0.2320 , with no evidence of publication bias. Given that we find no statistically significant effect in the LDCs sample, we conduct a PEESE analysis for the full sample and the developed countries sample only. Results are reported in Table 3. Here, results are consistent with PET-FAT results, except that the coefficient of the precision in the full sample regression dropped in magnitude from 0.0768 to 0.0366 , while in the developed countries sample, the coefficient increased from 0.2320 to 0.2514 . 
Table 3: PEESE results.

\begin{tabular}{|c|c|c|c|c|}
\hline \multirow[t]{2}{*}{ Variables } & \multicolumn{2}{|c|}{ Clustered data analysis } & \multicolumn{2}{|c|}{ Hierarchical model } \\
\hline & Full sample (1) & Developed (2) & Full sample (3) & Developed (4) \\
\hline \multirow{2}{*}{ Precision $\left(\beta_{0}\right)$} & $0.0579 *$ & $0.2027^{* * *}$ & $0.0366^{* *}$ & $0.2514^{* * *}$ \\
\hline & $(0.0283)$ & $(0.0436)$ & $(0.0173)$ & $(0.0496)$ \\
\hline \multirow[t]{2}{*}{ Std. error } & 4.3861 & $9.6771^{* *}$ & -8.6638 & 1.7036 \\
\hline & $(2.8480)$ & $(2.9905)$ & $(5.5019)$ & $(2.7728)$ \\
\hline Observations & 237 & 71 & 237 & 71 \\
\hline
\end{tabular}

Standard errors in parentheses.

$* * * 0<0.01, * * 0.05, * p<0.1$.

Thus, based on PET-FAT-PEESE analysis, we can conclude that (H1) government education expenditure as a share of GDP promotes growth and (H2) government education expenditure as a share of GDP promotes growth in developed countries, are supported. However, (H3) government education expenditure as a share of GDP promotes growth in less-developed counties (LDCs) is not supported.

\subsubsection{Addressing heterogeneity}

PET/FAT analyses do not account for moderating variables as they assume differences among reported estimates are due to sampling error alone. However, this is not the case in the GE-growth literature. Furthermore, it is important to explore issues of heterogeneity in the literature in order to identify the factors that cause variations in reported estimates. Thus, in what follows, we identify factors of heterogeneity among reported estimates, known as moderator variables, and conduct a multivariate meta-regression analysis (MRA) that examines the extent to which these factors affect the GE-growth relationship.

We extend equation (5) to yield a model which accounts for both heterogeneity and publication bias. Thus, equation (7) is an extension of equation (5), and allows for the inclusion of moderator variables.

$$
t_{j i}=\alpha_{0}+\beta_{0}\left(\frac{1}{S E_{j r i}}\right)+\sum \beta_{k} \frac{\left(Z_{k i}\right)}{S E_{j r i}}+v_{i j}+\varepsilon_{i j}
$$

Here, $Z_{k i}$ is a vector of moderator variables that may account for variations in the GE-growth relationship evidence base. We estimate equation (7) to account for model heterogeneity and account for data dependency. As done in the case of the PET/FAT analysis, the HLM estimation is our preferred model. In addition, we present two specification/model types - general model and the general-to-specific model. The more general specification contains all relevant dimensions and factors that are likely to affect the GE-growth relations. The specific model, however, is obtained by excluding, one at a time, the highly insignificant variables (i.e. those with the highest $p$-values) until statistical significance is attained for included moderator variables. This is done to reduce model complexity, and deal with issues of over-determination and multicollinearity. ${ }^{6}$

Moderator variables are systematic variations in primary studies that can potentially affect the nature of reported estimates. Given the GE-growth literature, our choice of moderator variables in this meta-analysis is informed by dimensions such as econometric specifications, theoretical reasoning, data differences and other difference in primary studies. Appendix Table 5 presents a description and summary statistics of the moderator variables used in our MRA. MRA results are reported in Table $4 .^{7}$ Both CDA and HLM results are reported.

Table 4: MRA results.

\begin{tabular}{|c|c|c|c|c|}
\hline \multirow[t]{2}{*}{ Variables } & \multicolumn{2}{|c|}{ Clustered data analysis } & \multicolumn{2}{|c|}{ Hierarchical model } \\
\hline & General (1) & Specific (2) & General (3) & Specific (4) \\
\hline \multirow[t]{2}{*}{ Precision } & 0.1690 & 0.2129 & 0.1927 & 0.1402 \\
\hline & $(0.3246)$ & $(0.1520)$ & $(0.1837)$ & (0.1308) \\
\hline \multirow{2}{*}{ Sample size } & 0.0918 & & -0.2568 & \\
\hline & $(0.6496)$ & & $(0.7736)$ & \\
\hline \multirow[t]{2}{*}{ LDCs } & 0.0472 & & 0.0306 & \\
\hline & $(0.0420)$ & & $(0.0431)$ & \\
\hline \multirow[t]{2}{*}{ OECD } & -0.1262 & & -0.1559 & \\
\hline & $(0.1269)$ & & $(0.1256)$ & \\
\hline
\end{tabular}


Control for

endogeneity

Cross section

Data average* panel

data

Endogenous growth model

Data average (=>5)

Data period (1980+)

Data period (1990+)

Data period (2000+)

Population

Initial GDP

Tax

Private investment

Political instability

Life expectancy

Government quality

Inflation

Openness

Journal rank

Journal

Publication year

(1990+)

Publication year

(2000+)

Constant

Observations
0.0627

(0.0386)

$0.4438^{* * *}$

(0.1418)

$-0.0831$

(0.0749)

$-0.2130^{* * *}$

(0.0713)

$0.3547^{* * *}$

(0.1157)

0.0482

(0.1583)

$-0.3062^{* * *}$

(0.1064)

0.0717

(0.0498)

$-0.3679^{* * *}$

(0.0687)

0.0751

(0.1358)

$-0.0799$

(0.0519)

0.0612

(0.1868)

$-0.2104$

(0.1307)

$0.4085^{*}$

(0.2295)

$-0.4398^{* *}$

(0.1789)

0.1284

(0.1384)

$-0.0832$

(0.1292)

$-0.2007^{* * *}$

(0.0562)

$0.3094^{* * *}$

(0.0983)

$-0.4251^{* * *}$

(0.0634)

0.0914

(0.0916)

0.0024

(2.0455)
0.0644

(0.0642)

$0.4054^{* * *}$

(0.1167)

$-0.0055$

(0.0881)

$-0.1255^{* *}$

$-0.1080^{* *}$

(0.0567)

$0.3312^{* * *}$

(0.0624)

$0.2647^{* *}$

(0.0504)

$0.3151^{* * *}$

(0.1166)

(0.0601)

(0.0758)

$-0.3351^{* * *}$

(0.0575)

$-0.1161^{* *}$

$-0.1821^{* *}$

(0.0712)

$0.3493^{* * *}$

(0.0814)

$-0.3096^{* * *}$

(0.0647)

0.0644

(0.0679)

$-0.1883^{* * *}$

(0.0539)

$0.2963^{* * * *}$

(0.0752)

$-0.3705^{* * *}$

(0.0981)

$0.1366^{* * *}$

(0.0347)

$-0.0648$

(0.4666)

237
$-0.2450^{* * *}$

(0.0872)

0.0711

(0.0570)

$-0.3094^{* * *}$

(0.0706)

0.1112

(0.0872)

$-0.0949^{*}$

(0.0486)

0.0252

(0.0873)

$-0.2477^{* * *}$

(0.0865)

$0.4205^{\text {*** }}$

(0.1289)

$-0.4353^{* * *}$

(0.1270)

0.1641

(0.1005)

$-0.0868$

(0.0884)

$-0.1972^{* * *}$

(0.0507)

$0.2744^{* * *}$

(0.1020)

$-0.3674^{* * *}$

(0.0986)

0.0803

$-0.2470^{* * *}$

(0.0768)

$-0.3242^{* * *}$

(0.0560)

$-0.1272^{* * *}$

(0.0442)

$-0.2376^{* * *}$

(0.0727)

$0.4269^{* * *}$

(0.0914)

$-0.3925^{* * *}$

(0.0989)

$0.1192^{*}$

(0.0718)

$-0.1952^{* * *}$

(0.0466)

$0.3098^{* * *}$

(0.0914)

$-0.3377^{* * * *}$

(0.0841)

$0.1223^{* *}$

$(0.0690) \quad(0.0562)$

0.8775

0.0292
$(0.4886)$

(2.1051)

(0.4886)

Standard errors in parentheses

${ }^{* * * *} p<0.01,{ }^{* * *} p<0.05, " p<0.1$.

\section{Data characteristics}

We first investigate if the GE-growth nexus is time variant. Thus, we include three dummy variables to capture the "recentness" of data used by primary studies. The first dummy variable captures studies that use data starting from 1980, while the second captures studies that include data starting from the 1990s and the last, starting from 2000s. Studies that use dataset with the starting year earlier than 1980 are excluded as base. From Table 4, based on HLM results, we find that the data period dummies are statistically insignificant except for the one. Specifically, we find that, as opposed to studies that do not, studies that use data from 1990 and beyond tend to report less positive effects of education expenditure on growth. 
We further examine if the GE-growth relationship is affected by sample type. Various studies have argued that expenditures on human capital investment, especially education, affect growth differently in developed and less developed countries (LDCs). Thus, we include a dummy for country type to examine if reported estimates are different based on the sample used. We include a dummy for LDCs and another for studies that report estimates on OECD countries. Our results show that the dummies for country types are statistically insignificant. Lastly, we consider the effects of the number of observations. Existing literature (see, e.g. Ray and Rivera-Batiz 2002) has demonstrated the effects of sample size in growth regressions. Thus, it is worthwhile to examine if the GE-growth relationship is influenced by sample size. MRA results report a statistically insignificant coefficient for sample size.

\section{Theoretical models and econometric specification}

Econometric specifications used in primary studies are often based on certain underlying theoretical models. The GE-growth relationship is likely to be affected by the underlying theoretical models which inform econometric model specifications. We examine if underlying theoretical models affect the GE-growth association. We control for studies that base their specifications on endogenous growth models while excluding studies that adopt the Solow-type growth model as base. The results show that studies that adopt specifications based on endogenous growth model report more negative effects of education expenditure on growth, compared to those that do not.

The first dimension of econometric specification that we capture is the length of time-period over which variables are averaged. The length of time over which variables are averaged in primary studies can potentially affect reported estimates. A number of arguments are usually presented in favor of data averaging. For instance, averaging over a period equal to the business cycle (usually 5 years) eliminates business cycle effects, especially if primary studies do not include measures of business cycle (e.g. output gap) in their models. Also, estimates based on data averaged over a period of 5 years or more can be interpreted as medium- to long-run effects as opposed to short-run effects. A common practice in the literature is the use of 5-years averaging. Some studies also use averaging periods greater than or less than 5 years. In our MRA, we control for time horizon to verify if the effect of education expenditure on growth is larger when the data period is averaged over periods equal to or longer than 5 years. Thus, we include a dummy for studies where data is averaged over a period of 5 years or more, and exclude other studies as base. We find that studies that use data averaging for periods equal to or greater than 5 years tend to report less adverse effects of education expenditure on growth.

We compare the differences reported in estimates presented by cross-section and panel data estimation. Some studies tend to rely on cross-section data averaged over long periods. However, cross-section estimations usually overlook country-specific fixed effects that may capture country-specific differences in cross-country regressions. Thus, in the presence of fixed-effects, cross-section estimates may be biased. Panel-data estimations, on the other hand, are able to address this source of bias by purging the country-specific fixed effects and focusing on temporal variations in the data. Therefore, we include a dummy that captures studies that use cross-section data and compare this with panel data. We find that the use of cross-section data (as opposed to panel data) is associated with less adverse effects of education expenditures on growth. This suggests that the use of cross-section data is likely to be a source of positive bias in the evidence base, and therefore it is likely that the positive effect of government education expenditures on growth in the policy debate may be based on incorrect inference. We also control for studies that use panel data and adopt data averaging of 5 years or more. The coefficient for this dummy is insignificant.

Next, we control for the covariates used in primary studies. In economics, it is general knowledge that the exclusion and/or inclusion of certain control variables can affect regression coefficients. This extends to the government expenditure-growth literature as well. For instance, studies such as Levine and Renelt (1992) present discussions on the issue and argue that major growth determinants include investment share of GDP, population growth rate and initial GDP, among others. Other key determinants of growth discussed in the literature include taxes, openness and inflation. Specific to the GE-growth literature, the role of institutions and governance, political stability (or instability) and life expectancy have been hypothesized as relevant factors that can affect growth. Thus, we control for studies that use all the above mentioned variables in order to examine if the exclusion/inclusion of such variables from primary study regressions affect reported research findings.

Overall, results indicate that the inclusion/exclusion of certain explanatory variables affect the nature of reported estimates. Specifically, we find that studies that control for population growth rate, political instability, tax and government quality (as opposed to those that do not) are predisposed to report more adverse effects, while those that control for life expectancy and inflation tend to report less adverse effects. Dummies for studies that control for private investment, openness and initial GDP are statistically insignificant. Thus, overall, while consistency is not observed for these dummy variables, it is obvious that the inclusion or exclusion of key growth determinants can significantly alter the nature of reported estimates. 
Lastly, OLS estimates are inconsistent and biased in the presence of endogeneity, making inferences misleading. Thus, studies on the relationship between government expenditures and economic growth control for endogeneity using instrumental variable (IV) techniques. In this tradition, a number of primary studies that examine the GE-growth association address endogeneity by adopting various IV techniques instead of, or in addition to, non-instrumented methods such as OLS. Therefore, in our MRA, we control for studies that control for endogeneity as opposed to those that do not. This allows us to examine if the control for endogeneity yields systematically different effect-size estimates compared to other estimation methods that do not. We find that the dummy for studies that control for endogeneity is statistically insignificant.

\section{Publication characteristics}

With regards to publication characteristics, we first control for publication type, and examine if the estimates reported in journal articles are different compared to those reported in working papers and book chapters. We include a dummy for studies published in journals, and exclude working papers and book chapters as base. Results mainly suggest that publication type does affect the nature of reported estimates. Specifically, we find that journal articles as opposed to book chapters or working papers tend to report more positively on growth.

We also examine if the GE-growth association varies with the publication outlet used by primary studies. Therefore, we control for publication outlet by including a dummy for high-ranked journals. Studies such as Kalaitzidakis, Mamuneas, and Stengos (2011), Chang, Maasoumi, and McAleer (2016), and Wohlrabe (2016) provide ranking of journal quality. These studies provide rankings of economics journals based on journal influence and impact factor among others. We consider the top $25 \%$ of journals ranked in Kalaitzidakis, Mamuneas, and Stengos (2011) as high-ranking journals. ${ }^{8}$ Results show that studies published in high-ranked journals (as opposed to low-ranked journals) are predisposed to reporting more adverse effects.

Lastly, we also control for publication year in order to examine if the reported estimates on the GE-growth nexus change overtime in publications. Given that richer dataset and newer econometric techniques emerge over time, more studies are published to challenge the status quo. Thus, it is worthwhile to examine if the nature of reported estimates change as newer publications emerge. We include a dummy for studies that are published in the year 1990 and beyond, and those that are published in the year 2000 and beyond. We exclude other studies as base. Results suggest that newer studies tend to report more positive association between education expenditure and growth.

\section{Conditional effect on growth/common research practices}

The net growth effect of government education expenditures, in the context of the MRA, is conditional on moderator variables. Thus, we zoom in on various practices often adopted by researchers to examine what the net effect is on growth. We first consider studies that use OECD data, control for endogeneity and also adopt some variant of the endogenous growth model to inform their empirical model specification. In this category, we find a conditional effect of 0.2151 of government education expenditure on growth. Second, we find a conditional effect of 0.4134 for studies that examine the effect of education expenditure on growth applying methods that control for endogeneity on OECD data, and also control for taxes and initial GDP in their regressions. Third, for studies that use cross-section data on LDCs and control for taxes, we find a conditional effect of 0.3229 . Lastly, we examine the conditional effect of relatively new studies published with focus on LDCs. We note that the conditional effect of education expenditure on growth for studies that use 5-years or more data averaging on LDCs data and are published after 1999 is 0.2189. On average, it is observed that the conditional effect of government education expenditure on growth is stronger for developed countries (measured by the OECD) than LDCs.

Overall, taking into account MRA results and our conditional effects on growth which represent the measure of genuine effects that control for both publication bias and heterogeneity, we can conclude that government education expenditure has a positive effect on growth. Drawing on inferences made by both Cohen (1988) and Doucouliagos (2011), these effects are not trivial, and thus present meaningful and practical economic significance.

\section{Conclusions}

Based on 237 estimates drawn from 29 primary studies, we conduct a meta-analysis that examines the effect of government education expenditure (GE) on economic growth. Specifically, we examine the following three hypotheses: (H1) government education expenditure as a share of GDP promotes growth, (H2) government 
education expenditure as a share of GDP promotes growth in developed countries, and (H3) government education expenditure as a share of GDP promotes growth in less-developed counties (LDCs). Based on our results, the following major conclusions emerge.

The results from fixed effects weighted averages, bivariate precision effect and funnel asymmetry tests (PET/FAT), and multivariate meta-regression analysis (MRA) all indicate that there is a positive association between government education expenditure and growth. Thus, whether or not publication bias and/or moderator variables have been controlled for, the effect of government education expenditure on growth remains positive. Furthermore, using a sub-sample of developed countries, results show a positive and significant association between government education expenditure and growth. However, we find no statistically significant association in the case of LDCs.

Based on these findings, it is obvious that $(\mathrm{H} 1)$ and $(\mathrm{H} 2)$ are supported, but $(\mathrm{H} 3)$ is rejected. The results observed for LDCs could be explained by various findings within the exiting literature. For instance. our findings are consistent with ideas that human capital investment in LDCs are negatively influenced by poor institutions that do not permit proper allocation of funds within the educational sector (Belassi and Musila 2005). Further, most LDCs tend to invest into basic education while neglecting tertiary education. Of course, primary education serves as a prerequisite for tertiary education, however, studies such as Lucas (1990) and Vandenbussche, Aghion, and Meghir (2006) have emphasized tertiary education as the main cause of economic growth. Thus, without effective allocation of funds to support both the basic and tertiary education systems, the desired effect of education expenditure on growth may not be attained.

With regards to publication selectivity, we find that the GE-growth relationship is not fraught with issues of publication selection bias. We also find that primary study characteristics such as data type, period of data averaging, publication outlets used and variables included in econometric specification contribute to variations in reported effect sizes.

Concerning variables included in econometric specifications, MRA results indicate statistical significance for the dummies included for variables such as tax, population, life expectancy, inflation, political instability and government quality. This suggests that the growth impact of GE may change when these variables are omitted in primary study regressions since they are key growth determinants. Thus, the exclusion of such variables could lead to biased results in the GE-growth literature. It would be good practice for researchers to include key regressors in regressions with a view to minimize the risk of model specification bias and the additional heterogeneity resulting from such biases.

A number of suggestions emerge for future research. First, except for the introduction of dummies to capture the effect of country types, we are not able to thoroughly examine our hypotheses for country types owing to data constraints. ${ }^{9}$ In the future, given an increase in the number of primary studies that examine the GE-growth association, a course of future research would be to re-examine this association by splitting meta-observations to capture country types. Beyond the use of a dummy variable to capture the effect of country types, a thorough investigation which involves a separate multivariate meta-regressions analysis (MRA) for LDCs and developed countries can help shed light on the possible causes of heterogeneity in the literature examining each country type.

Second, with arguments that there are diminishing effects of human capital expenditure on growth, future studies need to examine empirically if the growth effect of government expenditure on education is non-linear. Our meta-analysis reveals that very few studies have examined the issue of non-linearity.

Lastly, a few studies are excluded from our meta-analysis because relevant statistics needed for the calculation of partial correlation coefficients are not reported. It is in the best interest of future research that standards be set regarding the inclusion of relevant statistics such as t-values and/or standard errors in primary studies.

\section{A Appendix Table}

Table 5: MRA Variables. 


\begin{tabular}{|c|c|c|c|}
\hline Variables & Definition & Mean & S.D. \\
\hline$t$-value & $\begin{array}{l}t \text {-statistics reported in } \\
\text { primary studies }\end{array}$ & 1.17 & 2.39 \\
\hline Precision & $\begin{array}{l}\text { Inverse of standard error of } \\
\text { the partial correlation } \\
\text { coefficient }\end{array}$ & 4.28 & 2.01 \\
\hline$S E_{r i}$ & $\begin{array}{l}\text { Standard errors of the } \\
\text { partial correlation } \\
\text { coefficients }\end{array}$ & 0.11 & 0.05 \\
\hline OECD & $\begin{array}{l}\text { Takes value } 1 \text { if the } \\
\text { primary study data is from } \\
\text { OECD countries, otherwise } \\
0\end{array}$ & 0.19 & 1.48 \\
\hline LDCs & $\begin{array}{l}\text { Takes value } 1 \text { if the } \\
\text { primary study data is from } \\
\text { LDCs, otherwise } 0\end{array}$ & 2.21 & 5.86 \\
\hline Sample size & $\begin{array}{l}\text { Log of number of } \\
\text { observations in primary } \\
\text { study }\end{array}$ & 12.67 & 4.63 \\
\hline Cross-section & $\begin{array}{l}\text { Takes value } 1 \text { if } \\
\text { cross-section data is used } \\
\text { by primary study, } 0 \text { if } \\
\text { panel is used }\end{array}$ & 3.54 & 6.74 \\
\hline Panel data & $\begin{array}{l}\text { Takes value } 1 \text { if panel data } \\
\text { is used by primary study, } \\
\text { otherwise } 0\end{array}$ & 7.54 & 7.74 \\
\hline Control for endogeneity & $\begin{array}{l}\text { Takes value } 1 \text { if primary } \\
\text { study controls for } \\
\text { endogeneity, otherwise } 0\end{array}$ & 1.72 & 3.84 \\
\hline Endogenous growth model & $\begin{array}{l}\text { Takes value } 1 \text { if the model } \\
\text { is based on endogenous } \\
\text { growth model, otherwise } 0 .\end{array}$ & 5.11 & 8.67 \\
\hline Data average $(=>5)$ & $\begin{array}{l}\text { Takes value } 1 \text { if data } \\
\text { averaging period is }=>5 \\
\text { otherwise } 0\end{array}$ & 6.26 & 6.10 \\
\hline Data average* panel data & $\begin{array}{l}\text { Takes value } 1 \text { if study used } \\
\text { panel data and averaging } \\
\text { period is }=>5 \text { otherwise } 0\end{array}$ & 3.75 & 6.25 \\
\hline Data period $(1970+)$ & $\begin{array}{l}\text { Takes value } 1 \text { if data } \\
\text { year }>=1970 \text {, otherwise } 0\end{array}$ & 7.93 & 8.18 \\
\hline Data period $(1980+)$ & $\begin{array}{l}\text { Takes value } 1 \text { if data } \\
\text { year }>=1980 \text {, otherwise } 0\end{array}$ & 2.66 & 5.79 \\
\hline Data period $(1990+)$ & $\begin{array}{l}\text { Takes value } 1 \text { if data } \\
\text { year }>=1990, \text { otherwise } 0\end{array}$ & 2.40 & 5.54 \\
\hline Data period $(2000+)$ & $\begin{array}{l}\text { Takes value } 1 \text { if data } \\
\text { year }>=2000 \text {, otherwise } 0\end{array}$ & 2.40 & 5.54 \\
\hline Initial GDP & $\begin{array}{l}\text { Takes value } 1 \text { if the } \\
\text { primary study control for } \\
\text { initial per capita GDP, } \\
\text { otherwise } 0\end{array}$ & 5.73 & 7.98 \\
\hline Population & $\begin{array}{l}\text { Takes value } 1 \text { if the } \\
\text { primary study control for } \\
\text { population, otherwise } 0\end{array}$ & 2.55 & 4.32 \\
\hline Private investment & $\begin{array}{l}\text { Takes value } 1 \text { if the } \\
\text { primary study control for } \\
\text { private investment, } \\
\text { otherwise } 0\end{array}$ & 4.31 & 7.78 \\
\hline Tax & $\begin{array}{l}\text { Takes value } 1 \text { if the } \\
\text { primary study control for } \\
\text { taxes, otherwise } 0\end{array}$ & 5.51 & 9.41 \\
\hline Openness & $\begin{array}{l}\text { Takes value } 1 \text { if the } \\
\text { primary study control for } \\
\text { openness indicators, } \\
\text { otherwise } 0\end{array}$ & 3.42 & 6.06 \\
\hline
\end{tabular}




\begin{tabular}{|c|c|c|c|}
\hline Inflation & $\begin{array}{l}\text { Takes value } 1 \text { if the } \\
\text { primary study control for } \\
\text { inflation, otherwise } 0\end{array}$ & 2.64 & 5.82 \\
\hline Journal rank & $\begin{array}{l}\text { Takes value } 1 \text { if the } \\
\text { primary study is published } \\
\text { in high-ranked journal, } \\
\text { otherwise } 0\end{array}$ & 6.48 & 7.75 \\
\hline Journal & $\begin{array}{l}\text { Takes value } 1 \text { if the } \\
\text { primary study is published } \\
\text { in a journal, otherwise } 0\end{array}$ & 9.72 & 8.15 \\
\hline Publication year (1990+) & $\begin{array}{l}\text { Takes value } 1 \text { if publication } \\
\text { year }>=1990 \text {, otherwise } 0\end{array}$ & 9.68 & 7.24 \\
\hline Publication year (2000+) & $\begin{array}{l}\text { Takes value } 1 \text { if publication } \\
\text { year }>=2000 \text {, otherwise } 0\end{array}$ & 6.39 & 7.27 \\
\hline Publication year (2010+) & $\begin{array}{l}\text { Takes value } 1 \text { if publication } \\
\text { year }>=2010 \text {, otherwise } 0\end{array}$ & 3.69 & 7.01 \\
\hline
\end{tabular}

MRA dummy variables are divided by $S E_{r i}$.

Table 6: Robustness Check with alternate measure of journal quality.

\begin{tabular}{|c|c|c|}
\hline \multirow[t]{2}{*}{ Variables } & \multicolumn{2}{|c|}{ Specific model } \\
\hline & CDA (1) & HLM (2) \\
\hline \multirow[t]{2}{*}{ Precision } & 0.2456 & 0.1824 \\
\hline & $(0.1559)$ & $(0.1370)$ \\
\hline \multirow[t]{2}{*}{ Cross section } & $0.4212^{* * *}$ & $0.4727^{* * *}$ \\
\hline & $(0.0838)$ & $(0.0929)$ \\
\hline \multirow[t]{2}{*}{ Endogenous growth model } & $-0.1785^{* * *}$ & $-0.1054^{* *}$ \\
\hline & $(0.0605)$ & $(0.0531)$ \\
\hline \multirow[t]{2}{*}{ Data average $(=>5)$} & $0.2656^{* * *}$ & $0.2737^{* * *}$ \\
\hline & $(0.0867)$ & $(0.0843)$ \\
\hline \multirow[t]{2}{*}{ Data period $(1990+)$} & $-0.3012^{* * *}$ & $-0.2637^{* * *}$ \\
\hline & $(0.1004)$ & $(0.0817)$ \\
\hline \multirow{2}{*}{ Population } & $-0.3108^{* * *}$ & $-0.3060^{* * *}$ \\
\hline & $(0.0600)$ & $(0.0589)$ \\
\hline \multirow[t]{2}{*}{ Tax } & $-0.1171^{* *}$ & $-0.1309^{* * *}$ \\
\hline & $(0.0481)$ & $(0.0495)$ \\
\hline \multirow[t]{2}{*}{ Political instability } & -0.1419 & $-0.2133^{* * *}$ \\
\hline & $(0.0838)$ & $(0.0784)$ \\
\hline \multirow[t]{2}{*}{ Life expectancy } & $0.3219^{* * *}$ & $0.4173^{* * *}$ \\
\hline & $(0.0958)$ & $(0.0961)$ \\
\hline \multirow[t]{2}{*}{ Government quality } & $-0.2169^{* *}$ & $-0.3400^{* * *}$ \\
\hline & $(0.0871)$ & $(0.1036)$ \\
\hline \multirow[t]{2}{*}{ Inflation } & -0.0219 & 0.0598 \\
\hline & $(0.0793)$ & $(0.0768)$ \\
\hline \multirow[t]{2}{*}{ Journal rank } & $-0.1854^{*}$ & $-0.1431^{*}$ \\
\hline & $(0.0771)$ & $(0.0782)$ \\
\hline \multirow[t]{2}{*}{ Journal } & $0.2229^{* *}$ & $0.2531^{* *}$ \\
\hline & $(0.0848)$ & $(0.0995)$ \\
\hline \multirow[t]{2}{*}{ Publication year $(1990+)$} & $-0.3662^{* * *}$ & $-0.3302^{* * *}$ \\
\hline & (0.1119) & (0.0958) \\
\hline \multirow[t]{2}{*}{ Publication year $(2000+)$} & $0.1591^{* * *}$ & $0.1270^{* *}$ \\
\hline & $(0.0384)$ & $(0.0591)$ \\
\hline \multirow[t]{2}{*}{ Constant } & 0.1467 & 0.0267 \\
\hline & $(0.4631)$ & $(0.5109)$ \\
\hline Observations & 237 & 237 \\
\hline
\end{tabular}

Robust standard errors in parentheses.

**** $p<0.01, * * p<0.05, * p<0.1$. 


\section{Notes}

${ }^{1}$ For instance, Landau $(1983,1986)$, Stroup and Heckelman (2001) and Afonso and Jalles (2013) find a positive effect of government education expenditure on growth, while Blankenau, Simpson, and Tomljanovich (2007) find a negative growth effect of government education expenditure.

${ }^{2}$ Keywords for GE include education expenditure, human capital, education spending. Keywords for growth include GDP, economic growth, gross domestic product, economic development.

${ }^{3}$ We conducted an exhaustive search for literature on education expenditures in general (i.e. government expenditures and also total education expenditures), however, very few studies were found to have examined total education expenditures and growth. More importantly, since our focus is to contribute to the literature which tries to determine the components of government expenditures that are productive/unproductive, we do not include total education expenditures in our meta-analysis.

${ }^{4}$ Cohen (1988) indicates that an effect size represents small effect if its absolute value is less than 0.10 , medium effect if it is 0.25 and over, and large if it is greater than 0.4. However, Doucouliagos (2011) indicates that the application of Cohen's guidelines to partial correlation coefficients understate the economic significance of empirical effect and thus, he proposes that effect size greater than 0.07 and 0.33 represent a "medium" and "large" effects, respectively.

${ }^{5}$ Our results may be biased if there are outlier estimates or observations with outlier influence. We follow Bollen and Jackman (1985) to verify if there are any outliers. Using the DFBETA approach, we did not identify any observations as influential, and thus we are not faced by major outlier issues.

${ }^{6}$ See Campos, Ericsson, and Hendry (2005) for a review of the literature on general-to-specific modeling.

${ }^{7}$ Given the relatively few studies that report estimates on developed and less-developed countries only, we are not able to run separate MRA analysis for the sub-samples.

${ }^{8}$ Although the number of journals ranked differ across these studies, there is a significant overlap between these rankings especially for journals classified as top tier. Thus, studies in our meta-analysis published in top-ranking journal [i.e. top $25 \%$ of Kalaitzidakis, Mamuneas, and Stengos (2011) ranking] consistently qualify as top-ranking in other journal rankings such as Wohlrabe (2016) as well. For robustness, we run regressions with an alternate ranking of journal quality. The Australian Business Dean's Council (ABDC) and the Australian Research Council (ARC) present classifications for journal quality. Journals are ranked in descending order of quality as $\mathrm{A}^{*}, \mathrm{~A}, \mathrm{~B}$ and $\mathrm{C}$. We introduce a dummy for $\mathrm{A}^{*}$ and A ranked journals (high quality), and use other ranks as base to examine the robustness of our results. Results for journal quality based on the ABDC ranking is consistent with our main results. Results for this regression are reported in the Appendix.

${ }^{9}$ Splitting our sample to conduct separate MRAs for LDCs and developed countries was not possible because the sample size in each category was not sufficiently large.

\section{References}

Afonso, A., and ]. T. Jalles. 2013. “Fiscal Composition and Long-Term Growth." Applied Economics 46 (3): 349-358.

Aghion, P., E. Caroli, and C. Carcía-Peñalosa. 1999. “Inequality and Economic Crowth: The Perspective of the New Growth Theories." Journal of Economic Literature 37 (4): 1615-1660.

Alptekin, A., and P. Levine. 2012. "Military Expenditure and Economic Growth: A Meta-Analysis." European Journal of Political Economy 28 (4): 636-650.

Baldacci, E., B. Clements, S. Gupta, and Q. Cui. 2004. “Social Spending, Human Capital, and Growth in Developing Countries: Implications for Achieving the MDGs."IMF Working Paper No. 04/217.

Baldacci, E., B. Clements, S. Cupta, and Q. Cui. 2008. “Social Spending, Human Capital, and Crowth in Developing Countries.” World Development 36: 1317-1341.

Barro, R., and J.-W. Lee. 1993. “International Comparisons of Educational Attainment.” Journal of Monetary Economics 32: 363-394.

Barro, R. J 1989. Economic Growth In A Cross Section OfCountries: University of Rochester - Center for Economic Research (RCER).

Barro, R. J 1991. "Economic Growth in a Cross Section of Countries." The Quarterly Journal of Economics 106 (2): 407-443.

Barro, R. J., and X. Sala-i-Martin. 1995. Economic Crowth. Cambridge, MA: MIT Press.

Barro, R. J., and X. Sala-i-Martin. 2004. Economic Crowth., 2nd ed. Cambridge, Massachusetts: The MIT Press.

Bassanini, A., and S. Scarpetta. 2001. “Does Human Capital Matter for Crowth in OECD Countries? Evidence from Pooled Mean-Croup Estimates."OECD Economics Working Paper No. 282.

Bateman, I., and A. Jones. 2003. “Contrasting Conventional with Multi-Level Modelling Approaches to Meta-Analysis: Expectation Consistency in U.K. Woodland Recreation Values." Land Economics 79 (2): 235-258.

Becker, Gary 1964. Human capital: a theoretical and empirical analysis, with special reference to education. Chicago: The University of Chicago Press. Belassi, W., and J. Musila. 2005. "The Impact of Education Expenditures on Economic Growth in Uganda: Evidence from Time Series Data." The Journal of Developing Areas 38 (1): 123-133.

Benabou, R 2002. "Tax and Education Policy in a Heterogeneous-Agent Economy: What Levels of Redistribution Maximize Growth and Efficiency?” Econometrica 70: 481-517.

Benhabib, J., and M. M. Spiegel. 1994. "The Role of Human Capital in Economic Development Evidence from Aggregate Cross-Country Data." Journal of Monetary Economics 34 (2): 143-173.

Benos, N., and S. Zotou. 2014. “Education and Economic Growth: A Meta-Regression Analysis.” World Development 64: 669-689.

Bils, M., and P. J. Klenow. 2000. “Does Schooling Cause Growth?" American Economic Review 90 (5): 1160-1183.

Blankeanu, W. F 2005. “Public Schooling, College Subsidies and Growth." Journal of Economic Dynamics and Control 29 (3): 487-507.

Blankenau, W. F., N. B. Simpson, and M. Tomljanovich. 2007. “Public Education Expenditures, Taxation, and Growth: Linking Data to Theory." American Economic Review 97 (2): 393-397.

Bojanic, A. N 2013. "The Composition of Covernment Expenditures and Economic Crowth in Bolivia." Latin American Journal of Economics 50 (1): 83-105. 
Bollen, K. A., and R. W. Jackman. 1985. "Regression Diagnostics an Expository Treatment of Outliers and Influential Cases." Sociological Methods \& Research 13 (4): 510-542.

Bose, N., M. E. Haque, and D. R. Osborn. 2007. “Public Expenditure and Economic Crowth: A Disaggregated Analysis for Developing Countries." Manchester School 75 (5): 533-556.

Campos, J., N. Ericsson, and D. Hendry. (2005)."Ceneral-to-Specific Modeling: An Overview and Selected Bibliography," FRB International Finance Discussion Paper. 838.

Caselli, F., G. Esquivel, and F. Lefort. 1996. "Reopening the Convergence Debate: A New Look at Cross-Country Crowth Empirics." Journal of Economic Growth 1 (3): 363-389.

Cassou, S., and K. Lansing. 2001. Tax Reform and Public Sector Investment in Human Capital.

Castelló-Climent, A 2008. “On the Distribution of Education and Democracy.” Journal of Development Economics 87 (2): 179-190.

Castelló-Climent, A., and R. Doménech. 2008. “Human Capital Inequality, Life Expectancy And Economic Growth." The Economic Journal 118 (528): 653-677.

Chang, C.-L., E. Maasoumi, and M. McAleer. 2016. “Robust Ranking of Journal Quality: An Application to Economics." Econometric Reviews 35 (1): 50-97.

Cohen, J 1988. Statistical Power Analysis for the Behavioural Sciences. N]: Hillsdale.

Colombier, C 2009. "Growth Effects of Fiscal Policies: An Application of Robust Modified M-Estimator." Applied Economics 41 (7): $899-899$.

Cooray, A. V (2009)."The Role of Education in Economic Crowth," Proceedings of the 2009 Australian Conference of Economists. 1-27.

Dalic, M 2013. "Fiscal Policy and Growth in New Member States of the EU: A Panel Data Analysis." Financial Theory and Practice 37 (4): $335-360$.

De Dominicis, L., R. Florax, and H. Groot. 2008. "A Meta-Analysis on the Relationship between Income Inequality and Economic Growth." Scottish Journal of Political Economy 55 (5): 654-682.

Demidenko, E 2004. Mixed Models: Theory and Applications. Hoboken, N]: Wiley.

Devarajan, S., V. Swaroop, and H.-f. Zou. 1996. "The Composition of Public Expenditure and Economic Crowth." Journal of Monetary Economics 37 (2): 313-344.

Diamond, ] 1998. “Fiscal Indicators for Economic Growth: The Covernment own Saving Concept Re-Examined." Journal of Public Budgeting, Accounting \& Financial Management 9 (4): 627-651.

Doucouliagos, H 2011. "How Large is Large? Preliminary and Relative Guidelines for Interpreting Partial Correlations in Economics." Deakin University, School of Accounting, Economics and Finance Working Paper Series 5.

Doucouliagos, H., and P. Laroche. 2009. “Unions and Profits: A Meta-Regression Analysis." Industrial Relations: A Journal of Economy and Society 48 (1): 146-184.

Doucouliagos, H., and T. Stanley. 2009. "Publication Selection Bias in Minimum-Wage Research? A Metaregression Analysis." British Journal of Industrial Relations 47 (2): 406-428.

Dunne, J. P., and N. A. L. Mohammed. 1995. “Military Spending in Sub-Saharan Africa: Some Evidence for 1967-85." Journal of Peace Research 32 (3): $331-343$.

Easterly, W., and S. Rebelo. 1993. “Fiscal Policy and Economic Crowth: An Empirical Investigation.” Journal of Monetary Economics 32 (3): $417-458$.

Eckstein, Z., and I. Zilcha. 1994. “The Effects of Compulsory Schooling on Growth, Income Distribution and Welfare.” Journal of Public Economics 53: 339-359.

Egger, M., D. Smith, M. Schneider, and C. Minder. 1997. "Bias in Meta-Analysis Detected by a Simple, Craphical Test." British Medical Journal 315: 629-634.

Glaeser, E. L., R. La Porta, F. Lopez-de-Silanes, and A. Shleifer. 2004. “Do Institutions Cause Growth?” Journal of Economic Growth 9 (3): 271-303.

Glomm, G., and B. Ravikumar. 1992. "Public versus Private Investment in Human Capital: Endogenous Growth and Income Inequality." Journal of Political Economy 100: 818-834.

Clomm, C., and B. Ravikumar. 1997. "Productive Covernment Expenditures and Long-Run Crowth." Journal of Economic Dynamics and Control 21 (1): 183-204.

Clomm, G., and B. Ravikumar. 1998. “Flat-Rate Taxes, Government Spending on Education, and Growth.” Review of Economic Dynamics 1 (1): 306-325.

Greene, W 2011. Econometric Analysis., 7th ed. New Jersey: Prentice Hall.

Hansson, P., and M. Henrekson. 1994. "A New Framework for Testing the Effect of Covernment Spending on Growth and Productivity." Public Choice 81 (3-4): 381-401.

Hanushek, E. A., and L. Woessmann. 2008. “The Role of Cognitive Skills in Economic Development." Journal of Economic Literature 46 (3): 607-668.

Henmi, M., and ]. B. Copas. 2010. “Confidence Intervals for Random Effects Meta-Analysis and Robustness to Publication Bias." Statistics in Medicine 29 (29): 2969-2983.

Islam, N 1995. “Growth Empirics: A Panel Data Approach.” The Quarterly Journal of Economics 110 (4): 1127-1170.

Kaganovich, M., and I. Zilcha. 1999. "Education, Social Security, and Growth." Journal of Public Economics 71: 289-309.

Kalaitzidakis, P., T. P. Mamuneas, and T. Stengos. 2011. "An Updated Ranking of Academic Journals in Economics." Canadian Journal of Economics/Revue canadienne d'économique 44 (4): 1525-1538.

Keller, K. R. I 2006. “Education Expansion, Expenditures per Student and the Effects on Crowth in Asia." Clobal Economic Review 35 (1): $21-42$.

Kelly, T 1997. "Public Expenditures and Growth." Journal of Development Studies 34 (1): 60-84.

Knight, M., N. Loayza, and D. Villanueva. 1993. "Testing the Neoclassical Theory of Economic Growth: A Panel Data Approach." StaffPapersInternational Monetary Fund 40 (3): 512-541.

Krueger, A. B., and M. Lindahl. 2001. “Education for Crowth: Why and For Whom?” Journal of Economic Literature 39 (4): 1101-1136.

Landau, D 1983. "Covernment Expenditure and Economic Growth: A Cross-Country Study." Southern Economic Journal 49 (3): $783-792$.

Landau, D 1986. "Covernment and Economic Growth in the Less Developed Countries: An Empirical Study for 1960-1980." Economic Development and Cultural Change 35 (1): 35-75. 
Landau, D. L 1997. “Covernment Expenditure, Human Capital Creation and Economic Crowth.” Journal of Public Budgeting, Accounting \& Financial Management 9 (3): 467-467.

Levine, R., and D. Renelt. 1992. “A Sensitivity Analysis of Cross-Country Crowth Regressions.” The American Economic Review 82 (4): $942-963$.

Lipset, S 1960. Political Man: The Social Bases of Politics. New York: Doubleday.

Lucas, R. E 1988. “On the Mechanics of Economic Development.” Journal of Monetary Economics 22 (1): 3-42.

Lucas, R. E 1990. “Why doesn't Capital Flow from Rich to Poor Countries?” The American Economic Review 80 (2): 92-96.

Mankiw, N. G., D. Romer, and D. N. Weil. 1992. “A Contribution to the Empirics of Economic Growth.” The Quarterly Journal of Economics 107 (2): 407-437.

McCulloch, C. E., S. R. Searle, and J. M. Neuhaus. 2008. Generalized, Linear, and Mixed Models., 2nd ed. Hoboken, N]: Wiley.

Miller, S. M., and F. S. Russek. 1997. “Fiscal Structures and Economic Growth: International Evidence.” Economic Inquiry 35 (3): 603-613.

Miyakoshi, T., Y. Tsukuda, T. Kono, and M. Koyanagi. 2010. "Economic Growth and Public Expenditure Composition: Optimal Adjustment Using the Gradient Method." Japanese Economic Review 61 (3): 320-340.

Mo, P. H 2007. "Covernment Expenditures and Economic Growth: The Supply and Demand Sides.” Fiscal Studies 28 (4): 497-522.

Mulligan, C. B., and X. Sala-I-Martin. 1993. "Transitional Dynamics in Two-Sector Models of Endogenous Growth." The Quarterly Journal of Economics 108 (3): 739-773.

Neycheva, M 2010. “Does Public Expenditure on Education Matter for Growth in Europe? A Comparison between old EU Member States and Post-Communist Economies." Post-Communist Economies 22 (2): 141-141.

Perotti, R 1996. “Growth, Income Distribution, and Democracy: What the Data Say.” Journal of Economic Growth 1 (2): 149-187.

Pritchett, L1996. “Where Has All the Eduation Cone?.”The World Bank, Policy Research Working Paper 1581.

Ray, J., and F. L. Rivera-Batiz. 2002. "An Analysis of Sample Selection Bias in Cross-Country Crowth Regressions."Columbia University, Department of Economics Discussion Paper No. 0102-10.

Romer, P. M 1986. "Increasing Returns and Long-Run Growth." Journal of Political Economy 94 (5): 1002-1037.

Rosen, S 1976. "A Theory of Life Earning." Journal of Political Economy 84: S45-S67.

Schultz, T. W 1961. “Investment in Human Capital." American Economic Review 61: 1-17.

Singh, R. J., and R. Weber. 1997. “The Composition of Public Expenditure and Economic Crowth: Can Anything Be Learned from Swiss Data?” Schweizerische Zeitschrift fur Volkswirtschaft und Statistik/Swiss Journal of Economics and Statistics 133 (3): 617-634.

Stanley, T 2008. "Meta-Regression Methods for Detecting and Estimating Empirical Effects in the Presence of Publication Selection." Oxford Bulletin of Economics and Statistics 70 (2): 103-127.

Stanley, T. D., and H. Doucouliagos. 2010. "Picture This: A Simple Graph That Reveals Much Ado about Research." Journal of Economic Surveys 24 (1): 170-191.

Stanley, T. D., and H. Doucouliagos. 2014. "Meta-Regression Approximations to Reduce Publication Selection Bias." Research Synthesis Methods 5 (1): 60-78.

Stanley, T. D., and H. Doucouliagos. 2016. “Neither Fixed nor Random: Weighted Least Squares Meta-Regression.” Research Synthesis Methods. n/a-n/a. DOI:10.1002/jrsm.1211.

Stanley, T. D., H. Doucouliagos, M. Giles, J. H. Heckemeyer, R. J. Johnston, P. Laroche, J. P. Nelson, M. Paldam, J. Poot, G. Pugh, R. S. Rosenberger, and K. Rost. 2013. “Meta-Analysis of Economics Research Reporting Guidelines." Journal of Economic Surveys 27 (2): 390-394.

Stroup, M., and J. Heckelman. 2001. "Size Of The Military Sector And Economic Growth: A Panel Data Analysis Of Africa And Latin America." Journal of Applied Economics 4 (2): 329-360.

Sutton, A. J., and J. Higgins. 2008. "Recent Developments in Meta-Analysis." Statistics in Medicine 27 (5): 625-650.

Sylwester, K 2000. “Income Inequality, Education Expenditures, and Growth." Journal of Development Economics 63 (2): 379-398.

Uzawa, H 1965. “Optimal Technical Change in an Aggregate Model of Economic Growth.” International Economic Review 6: 18-31.

Vandenbussche, J., P. Aghion, and C. Meghir. 2006. "Growth, Distance to Frontier and Composition of Human Capital." Journal of Economic Crowth 11 (2): 97-127.

Wigger, B. U 2004. “Are Higher Education Subsidies Second Best?" Scandinavian Journal of Economics 106: 65-82.

Wohlrabe, K 2016 (January). “Taking the Temperature: A Meta-Ranking of Economics Journals.” Ceslfo WP 57261-31.

Yan, C., and L. Cong. 2009. “Government Expenditure, Taxation and Long-Run Growth." Frontiers of Economics in China 4 (4): $505-525$.

Zhang, ] 1996. “Optimal Public Investment in Education and Endogenous Growth." Scandinavian Journal of Economics 98: 387-404.

Zhang, J., and R. Casagrande. 1998. “Fertility, Growth, and Flat-Rate Taxation for Education Subsidies.” Economics Letters 60 (2): $209-216$. 